96, he takes geologists to task for not making their descriptions to fit in with his delineation of purely superficial features. He reproaches the authors of the "Manual of the Geology of India" wilh adopting an "antiquated theory" which had been disposed of by his demonstration of a second line of peaks in the Himalayan range. The omission to account for such apparent neglect of recent discovery was solely due to the perceptions of its almost irrelevancy to the matter in hand. The old familiar feature for which Mr. Saunders claims such geographical importance (which the writers were not concerned to dispute) happens to be of quite incidental significance in the mountain-structure, and much more in accordance with "the antiquated theury" than with the independent position Mr. Saunders would assign to it. Also, the fact that the great gneissic axis of the Himalayan range divides into several minor axes west of the Sutlej, and that these disappear under fossiliferous formations before reaching the Indus, will probably be held by geologists as sufficient reason for considering this ground as the natural termination of the range. On the other hand, the fact that there should be a continuous watershed between these terminal ridges and the contiguous ridges of a confluent system of disturbance, will be admitted by geologists as sufficient for a combined hydrographical delineation of the two systems, as proposed $\mathrm{by} \mathrm{Mr}$. Saunders. The points of view of the pure geographer and of the geologist are at present so wide apart that it is irrational to represent them as conficting.

Calcutta, December 3I, I879

\section{Ice Filaments}

THE phenomenon alluded to by the Duke of Argyll in NATURE, vol, xxi. p. 274, is not at all of unfrequent occurrence. I remember having been struck by the beauty of these ice-filaments on dead branches in Epping Forest many years ago, and some friends of mine observed some beautiful specimens of such branches in Surrey some few weeks since. The explanation which I have been inclined to give is the following:-During the moist weather preceding the frosts, the dead branches on the ground become sodden with water; the interstices between the cells of the dead ligneous fibre get saturated by capillarity, and the branches become water-logged. Now if a certain amount of dry weather intervenes between the moist period and the frost, this absorbed water would have time to partially evaporate and leave the branches more or less dry. But if the frost imme diately follows the moist period-as pointed out by the Duke of Argyll-there is no time for the drying of the branches, and the interstitial water becomes frozen in si:u. Under these circum. stances the expansive force of the ice would cause it to flow out from every available pore by virtue of its viscosity, and such $I$ take it is the origin of the flaments observed. Those portions of the branches which are protected by bark are sheathed by the latter in such a manner that the ice is prevented from oozing outwards; but my friends who have recently observed the phenomenon inform me that where the bark was partly separated from the wood beneath it so as to leave a small intermediate space, this space was likewise filled with flamentous ice.

All physicists are familiar with the experiment of $\mathrm{su}^{\text {' mitting }}$ fragments of ice to great pressure in a steel mould with an opening in it. The ice becomes consolidated by regelation, and flows out of the opening in a continuous thread. The state of affairs in frozen water-logged branches could thus be imitated by having a steel mould sufficiently strong to bear the pressure, completely filled with water and perforated by capillary holes, and then freezing the contents. The ice would, under these circumstances, flow out of the capillary holes in the filamentous form observed, and if a metal band were firmly fastened round the mould so as to sheath a certain zone of the capillary holes, no ice could appear in this zone, which would thus represent the portions of the branches protected by bark.

From the point of view of this explanation, which I venture to submit for the judgment of physicists, the Duke is hardly correct in speaking of this filamentous form of ice as an "icecrystal."

2I, John Street, Bedford Row, W.C., January 23 R. MELDOLA

THE filamentous form of ice-crystal, described by the Duke of Argyll as occurring upon rotten wood when a frost sets in suddenly after moisture, is by no means uncommon also upon chalk and other porous kinds of stone. It appears to arise from the water with which the body is soaked being extruded by the expansion due to cold when near its freezing-point, and becoming solidified as it passes the surface of the substance. It is, as it were, spun out of the pores of the rotten wood or porous stone. This explanation accounts for the fact, noticed by his Grace, that this form of crystal is not found upon those parts of a decayed branch upon which the bark is unbroken.

Harlton, Cambridge, January 23

O. FISHER

WHILE residing upon the South Downs I observed, during hard frosts, that prisms of ice exuded from small pieces of chalk, and having their sections identical with the piece of chalk. It is clear that the prism was formed by the moisture passing through the chalk by capillary attraction. May not this explain the formation of the filaments described by the Duke of Argyll ?

H. KING

\section{The Kangaroo}

I NOTICE in NATURE, vol. xx. p. $5 \mathrm{II}$, in a lecture on "Tails," the following remarks in reference to kangaroos :-

"These creatures make use of their tails not only sometimes to carry grass, and to a certain extent in their jumps," \&c. Permit me to state that the former statement is perfectly erroneous and the latter one is correct only in a very modified degree. Kangaroos cannot use their tails to carry grass, and never attempt it, and the use of their tails in jumping is confined to balancing the body, and whatever leverage may be exerted in the swaying of it when in notion. The tail never touches the ground in going. Twenty years' observation in three colonies is my authority for saying so.

Sydney, N.S.W., December 30, 1879

\section{Chinese Geese}

IT may interest some who read Mr. Darwin's note on this variety, to know that there are-or were only a few months ago - a rather large number of hybrids, of apparently all grades, at the Bristol Zoological Gardens. When I was there in September there was quite a respectable flock, pure Chinese being among them.

I have not unfrequently found both the pure variety and hybrids in the country, and have usually found that the people regarded them merely as a variety. The differences mentioned by Mr. Darwin seem scarcely so great as those presented by the Polish fowl-which also, by the way, seems almost to have been regarded as a species by some naturalists of good repute.

LEWIS WRIGHT

\section{The Molecular Velocity of Gases}

IN NATURE, vol. xxi. p. 20r, which reached me only recently, I find a letter of your correspondent " $K$ ", to whom I am much obliged for having pointed out to me an errorinto which I had fallen, in common with many others. I may quote, e.g., the exhaustive work of Rühlmann, 1 where, in the chapter on the history of the molecular theory, Joule is only alluded to, and immediately afterwards the theory of Krönig is given in extenso, without any hint that it is practically identical with that given by Joule in 1848 . Having read " R's" letter, I immediately procured the original article of Joule, and I am now ready to admit that Joule's article contains all that is essential to Krönig's method of computing the velocity of gas molecules. It is true, the formula itself as an algebraical expression is not found there, but the calculations given are to all purposes equivalent to the formula.

It is scarcely necessary to add that this makes no difference at all in reference to the contents of my letter in NATURE, vol. xxi. p. I76, referring, as it does, only to the historical footnote.

Prague, Spálená ulice, 2 nové, January 20

L. HAJNIŠ

\section{Suicide of the Scorpion}

SINCE writing mine of the 12 th inst. I have, I believe, discovered in Byron's "Giaour" the scientific (?) flight of fancy upon which Dr. R. F. Hutchinson based his central glowing I "Handbuch der mechanischen Wärmetheorie." 